\title{
Patrimonio inmaterial, comunidade e familia na antroponimia da Galicia inte- rior (ss. XVII-XIX)
}

\author{
Tamara González López ${ }^{1}$
}

Recibido: 15 de xuño de 2019 / Aceptado: 28 de outubro de 2019

Resumo. O nome constituía unha posesión inmaterial que se recibía no bautismo e conformaba unha das principais pezas da identidade do neonato. A súa escolla respondía a uns parámetros que foron mudando conforme ao contexto, pero que, na práctica, mantiña o simbolismo que o vinculaba coa familia carnal e espiritual, así coma coa propia comunidade na que a persoa se integraba. Non se trataba da simple asignación dun nome, senón que ese nome acostumaba ser transmitido por unha persoa do seu entorno a modo de dádiva inmaterial e de demostración da relación existente. Analizar as vías de asignación ilustra a evolución que o repertorio onomástico do interior galego tivo ao longo do Antigo Réxime, amosando a forte relevancia que a familia e a comunidade tiveron. Contribúe, amais, a explicar as razóns que levaron á pronta incorporación de determinados nomes que non pertencían á onomástica tradicional galega, así como o rexeitamento a outros nomes.

Palabras chave: patrimonio inmaterial; antroponimia; Lugo; familia; bautismo; apadriñamento.

\section{[es] Patrimonio inmaterial, comunidad y familia en la antroponimia de la Galicia interior (ss. XVII-XIX)}

Resumen. El nombre constituía una posesión inmaterial que se recibía en el bautismo y que conformaba una de las principales piezas de la identidad del neonato. Su elección respondía a unos parámetros que fueron cambiando según el contexto, pero que, en la práctica, conservaba el simbolismo que lo unía a la familia carnal y espiritual, así como a la propia comunidad en la que el recién nacido se integraba. No se trataba de la simple asignación de un nombre, sino que ese nombre acostumbraba a ser transmitido por una persona de su entorno, a modo de dádiva inmaterial y de demostración de la relación existente. Analizar las vías de asignación ilustra la evolución que el repertorio onomástico del interior gallego tuvo a lo largo del Antiguo Régimen y se muestra la fuerte relevancia en ello de la familia y la comunidad. Contribuye, además, a explicar las razones que llevaron a la rápida incorporación de ciertos nombres que no pertenecían al repertorio onomástico tradicional gallego, así como el rechazo a otros.

Palabras clave: patrimonio inmaterial; antroponimia; Lugo; familia; bautismo; padrinazgo.

\section{[en] Intangible Heritage, Community and Family in the Anthroponymy of the In- terior of Galicia (17th-19th centuries)}

\begin{abstract}
The name constituted an intangible heritage which was received in the baptism; also, it became a principal part of newborn's identity. The circumstances had influence the choice of the name, so the repertoire was changing just as the context; but, the name always conserved the symbolism about blood and spiritual family and of the community in where the baptised was born. It wasn't a simple assignment of a name because the name used to be transmitted by a person close to the baptised, as an intangible gift and a demonstration of the relationship. The evolution of onomastic repertoire of the interior of Galicia can be showed when we analyze the transmission ways and their impact; also, it illustrated the importance of the family and the community in anthroponymy's tendencies. In addition, it contributed to explain the reasons for the fast incorporation of certains names which didn't belong to galician traditional repertoire, just as the refusal of others.
\end{abstract}

Keywords: Intangible Heritage; Anthroponymy; Lugo; Family; Baptism; Godparenthood.

1 Universidade de Santiago de Compostela, Departamento de Historia.

Correo-e: tamara.gonzalez.lopez@usc.es 
Sumario. 1. Introdución. 2. Área de estudo: a diocese de Lugo. 3. A orixe dos nomes: tradición e modernidade. 3.1. Nomes da familia carnal. 3.2. Nomes da familia espiritual. 3.3. Nomes dos santos da comunidade. 4. Conclusións. 5. Referencias bibliográficas.

Como citar: González López, T. (2019): "Patrimonio inmaterial, comunidade e familia: antroponimia na Galicia interior (ss. XVII-XIX)", en Madrygal. Revista de Estudios Gallegos 22, pp. 193-208.

\section{Introdución ${ }^{2}$}

A antroponimia na Idade Moderna estaba marcada por unha serie de prácticas culturais que determinaron o repertorio existente. De certo, as influencias externas supuxeron a difusión de novos nomes que, en función da receptividade que amosaron as comunidades, proporciónannos información sobre as mentalidades e a apropiación do alóctono.

No presente texto, non pretendemos facer un repertorio dos nomes máis asignados no interior galego, senón que o obxectivo é explicar a constitución dese repertorio afondando nas causas da asignación dos nomes. Impor un nome a un cativo respondía a unha intencionalidade clara e non aleatoria que, ademais, situaba aos pais en varios dilemas complexos (Ballesteros Díez 2004: 29-30). Por unha banda, o dilema de manterse na tradición e nos nomes considerados de familia ou sucumbir a novas modas; por outra banda, de optaren por nomes dos parentes próximos, o dilema de quen era o escollido para transmitir o seu nome. E, dende estes dilemas, abríanse múltiples cuestións máis. Dende logo, nunha sociedade xerárquica e cunhas prácticas sucesorias e sociais marcadas, non tiña o mesmo impacto nin intencionalidade asignar o nome do avó paterno có da avoa, e, incluso, cambiaba en función de se estes vivían ou xa faleceran. Incluso, optando por un nome máis neutral e utilitario como era o santoral, abríase a dúbida de asignar o nome do santo do día do nacemento ou do bautismo.

Dito isto, o noso obxectivo é analizar a orixe dos nomes asignados e tentar explicar a causalidade que escondían estes. Pártese da base de que os nomes eran considerados máis ca un elo da identidade persoal (Salinero 2010: 14), pois era un elemento simbólico no que estaba depositado o acervo non só da familia, senón da comunidade.

\section{2. Área de estudo: a diocese de Lugo}

Malia que poda parecer desconexo, para comprender a transmisión e o valor inmaterial dos nomes asignados aos bautizados é preciso coñecer o contexto sociodemográfico. A diocese de Lugo era un territorio eminentemente rural, polo que a expansión de novos nomes non presentaba o mesmo ritmo nin o mesmo equilibrio xeográfico. A efectos de difusión das novidades onomásticas, os principais focos eran a cidade de Lugo e a vila de Monforte de Lemos. $\mathrm{O}$ resto do territorio estaba fragmentado en múltiples parroquias cunha poboación reducida: 44,6 veciños por parroquia de media (Rey Castelao 2002: 97-98).

A fidalguía constituía a cúspide social xunto co clero, a pesar de que a súa situación económica non sempre era vantaxosa. Ambos sectores constituían unha parte substancial da poboación, en tanto os primeiros representaban o 8\% (Presedo Garazo 2004: 119) e o clero o $3,6 \%$ a mediados do século XVIII: unha media de 1,61 eclesiásticos por parroquia (Rey Castelao 2002: 125). Estas cifras precisan de matices, pois a fidalguía tiña unha presenza maior nas áreas urbanas e, pola súa parte, o clero amosaba unha desigual distribución territorial, xa que as zonas de montaña albergaban menos eclesiásticos cás zonas de vales.

De igual xeito, tanto o factor urbano como o referente ao relevo condicionaban os modelos de estrutura familiar predominante en cada zona. O territorio que comprendía á diocese de Lugo presentaba, a mediados do século XVIII, os maiores índices de corresidentes no fogar de Galicia, así como a maior proporción de estruturas familiares complexas (Dubert García 1992: 72 e 103-108). A media de fillos por matrimonio situábase en 4,3, media que ascendeu a 5,1 no século XIX (Sobrado Correa 1996: 11), grazas a un descenso da mortalidade infantil, entre outros factores, que dende o século XVIII foise reducindo e chegou a inicios do século XX a cifras inferiores ao $12 \%$ (Saavedra Fernández 1992: 62; Muñoz López 2001: 256). Todo isto implica, pois, un alto número

2 Traballo realizado no marco do Proxecto de Investigación "El monte comunal en Galicia desde comienzos de la edad moderna a la actualidad: de soporte de un viejo complejo agrario a recurso medioambiental y patrimonio paisajístico", financiado pola Axencia Estatal de Investigación e Fondos FEDER da Unión Europea (HAR2014-52667-R). 
de corresidentes no mesmo fogar que debían conxugar a repetición de nomes para manter o repertorio de nomes familiares con tratar de evitar unha alta homonimia dentro do fogar que supuxese un obstáculo á convivencia.

Outra característica que debemos ter en conta á hora de analizar o impacto da antroponimia da comunidade é o alcance xeográfico dos matrimonios. A diocese lucense amosa altas proporcións de exogamia parroquial dos matrimonios: no século XVIII, o $65,8 \%$ dos cónxuxes procedían de parroquias distintas; mais, adoitaba tratarse de parroquias limítrofes ou a escasa distancia (Sobrado Correa 2001a: 132-134). A efectos da antroponimia, isto permitía o mantemento de certos cultos tanto relativos á igrexa parroquial como aos santuarios ou ermidas da zona entre aqueles que se casaban fóra da súa freguesía. Neste senso, está constatada a correlación existente entre a endogamia e a transmisión onomástica (Fine 1984: 110); a maior grado de endogamia, maiores índices de transmisión que se explican por unha menor circulación dos nomes e, por extensión, un repertorio máis reducido. Así, ademais de vontade de transmitir, tamén había máis probabilidades de recibir un nome xa existente no entorno próximo.

Veremos, a continuación, os efectos que estas características sociodemográficas tiveron na antroponimia da zona e como axudaron a modelala.

\section{A orixe dos nomes: tradición e moderni- dade}

Para analizar a orixe e causalidade da asignación de nomes, debemos partir do momento no que se recibía o nome oficial: o bautismo. Este era o primeiro sacramento recibido polos católicos que marcaba o momento de entrada na familia e na comunidade de fieis. Nel estaban presentes obrigatoriamente o clérigo e os padriños, que podían ser un home e unha muller, só un home ou só unha muller. Amais, era opcional e frecuente que acudise o pai e, dependendo de onde residían e de se estaban vivos, os avós maternos e paternos. A carón deles, tamén podían estar outros familiares e veciños que exercían como testemuñas, aínda que conforme avanzamos cara o século XIX, as celebracións do bautismo tenderon a realizarse nun contexto máis privado (Alfani e Gourdon 2009: 172-173). Quen non estaba presente era a nai por mor de ser considerada impura tras o parto, polo que non podía entrar ao templo parroquial ata someterse á cerimonia de purificación corenta días despois. Malia que o tempo que se esperaba para bautizar oscilou entre o século XVII e o XIX, este non superaba os oito días, polo que a nai só estivo no bautismo de seus fillos en situacións excepcionais ${ }^{3}$.

Por conseguinte, partindo do contexto no que se realizaba o bautismo e da información que se proporciona nas partidas bautismais, podemos establecer varias procedencias do nome: a familia carnal -pais e avós-, a familia espiritual -os padriños- e a procedencia relixiosa, na que podemos incluír a persoas físicas, como o eclesiástico bautizante, e a persoas incorpóreas -o santo patrón da parroquia ou de ermidas e o santo da onomástica do día de nacemento ou do bautismo. Cómpre matizar que a familia carnal e a espiritual podían coincidir ao seren os avós ou outros familiares os que exercían de padriños. A causalidade da asignación de nomes podía ter outras orixes como o señor titular da xurisdición, familiares falecidos ou, incluso, o gusto pola eufonía do nome; mais só temos acceso ás citadas orixes pola inclusión dos datos sobre eles nas partidas bautismais. Desgraciadamente, anotacións como a da partida do pequeno Francisco Antonio na que se da conta de quen e o porqué escolleu o nome son anecdóticas: "púsole por nombres Francisco Antonio, santos de la devoción de los padrinos"4. Este descoñecemento obriga, pois, a catalogar a orixe de certos nomes como "sen relación coñecida", malia que unha parte deles tiveran unha causalidade clara para o seu entorno.

Entre os nomes que si podemos encadrar a súa orixe, debemos citar o obstáculo que supón a forte homonimia existente entre a poboación. O repertorio estaba composto por un grupo de nomes que se poden considerar infrecuentes e por outro de nomes habituais. Neste último entraban aproximadamente, dependendo do

3 Moratinos y Santos 1675, Lib. III, Tít. XIV, Const. II. Unicamente se permitía superar ese prazo cando se administraba un bautismo de socorro ao nacer, situación na que se permitía esperar quince días para levalo ao templo parroquial.

4 Arquivo Central Parroquial da Diocese de Lugo [ACPDLu], Libro V Bautismos (1833-1847), Santa María da Régoa, f. 143 . 
período no que nos situemos, dúas decenas de nomes que representaban máis do $75 \%$ dos asignados. Esta concentración estaba na vida cotiá e, en consecuencia, había varios portadores do nome que recibía o bautizado no seu entorno. Por exemplo, en 1808 foi bautizado co nome de Santiago o fillo de Juan Antonio Lolo e Basilisa López, veciños de San Cristovo de Lóuzara; pese a non ser un nome dos máis frecuentes, chamábanse Santiago o padriño do cativo, Santiago Vila, o avó paterno, Santiago Lolo, e o avó materno, Santiago Vergara ${ }^{5}$. Isto supón un obstáculo metodolóxico importante porque non estamos en condicións de aseverar cal destas persoas era o motivo real, de aí que as proporcións de transmisión de certos sectores estean sobrevaloradas.

De xeito semellante, outra cuestión que debemos precisar é que tomamos como base o número de nenos bautizados e non o número total de nomes asignados. Aspecto importante especialmente no século XVIII, cando só o $19,55 \%$ dos bautizados recibían un só nome, xa que predominaban os nomes múltiples nos que se podía chegar a superar a decena. Co gallo de analizar o patrimonio inmaterial procedente da familia e da comunidade, consideramos máis funcional tomar como base os nenos, posto que é máis ilustrativo saber cantos cativos recibían un nome do seu entorno ca cantos nomes.

Tamén debemos apuntar que empregamos os nomes na súa versión castelá dado que era na que se redactaban as partidas bautismais; pero tanto os rexistros máis antigos como a anotación dos restantes familiares amosan a convivencia coa versión galega (Boullón Agrelo 2007: 19; Kintz 1984: 231-232). Na partida de bautismo de Marina (1668), bautizada na cidade de Lugo, a súa madriña foi rexistrada co nome galego, Mariña de Rubinos, ao contrario que a súa afillada ${ }^{6}$. Esta situación de diverxencia entre o nome que constaba nos rexistros oficiais escritos e o usado no plano oral cotiá atéstase naquelas áreas cunha lingua vehicular propia e outra imposta na escrita (Salinero 2010: 13).

A pregunta principal ao analizar os nomes asignados é quen tomaba a decisión. Había varias orixes plausibles, pero alguén era o que resolvía escollendo un nome. A escolla aparentaba libre, pero había múltiples condicionantes internos e externos á familia. Tomábase en consideración a estrutura do poder familiar, a descendencia previa, a función identificadora do nome, así como o seu valor social; pero, sobre todo, había unhas normas de nominación consuetudinarias ás que se gorecer (Salazar Acha 2005: 181). Nas respostas dadas á enquisa do Ateneo de Madrid en 1901-1902, as respostas oscilan entre quen afirmaban que era unha decisión paterna e os que alegaban que se trataba dunha prerrogativa dos padriños; aínda que tamén houbo espazo ás contestacións máis salomónicas de que se poñían de acordo padriños e pais (González Reboredo e Mariño Ferro 1990: 59-61).

Así e todo, a última decisión recaía no párroco quen anotaba a partida bautismal que constituía o rexistro escrito do nome e, polo tanto, o que tiña validez ante as administracións, sobre todo conforme se intensificou a burocratización do estado no século XIX (Herzog 2007: 22-23). $\mathrm{O}$ párroco podía actuar co consentimento dos pais e padriños recomendándolles certos nomes (Sobrado Correa 1998: 69); especialmente do santoral, que era a única normativa sobre nomes da Igrexa: "y a los bautizados les pongan nombre de algún santo, o santa, y no de gentiles, $o$ de otros que no sean bautizados"7. Pero tamén cabía a posibilidade de que o párroco anotase un nome máis na partida bautismal sen consultar coa familia ou, incluso, que se considerase coa potestade de impoñelo. Este tipo de abusos non debían ser infrecuentes, en tanto algúns manuais do século XIX detíñanse a especificar que o cura "recibe el nombre, no le impone" (Bedoya $1825: 207)$.

Así pois, para analizar o valor dado aos nomes asignados é preciso ter en conta que existían diversas orixes así como actores que decidían sobre eles.

\subsection{Nomes da familia carnal}

A familia carnal á que temos acceso a través das partidas bautismais eran os pais e os avós de ambas ramas. Ademais da citada homonimia, as cifras de transmisión dos avós están acrecentadas

ACPDLu, Libro IV Bautismos (1782-1826), San Cristovo de Lóuzara y Santo André de Gundriz, f. 243.

ACPDLu, Libro I de Bautismos, Matrimonios y Defunciones, (1620-1726), San Pedro de Lugo, f. 53v.

Constituciones sinodales del Obispado de Lugo de D. Diego Vela, Vda. Alonso Martín de Balboa, 1632, Lib. III, Tít. XIV, Const. 6. 
pola progresiva escolla da familia carnal como padriños a partir da segunda metade do século XVIII; polo tanto, unha parte dos avós que transmitían o seu nome facíano dende a posición de padriño máis que pola de avó.

Dado que no modelo de partida bautismal que proporcionaban as distintas constitucións sinodais do século XVII da diocese de Lugo non se obrigaba a anotar o nomes dos avós, o seu rexistro foi tardío e dependeu do nivel de obediencia aos visitadores que recomendaban a súa inclusión. Por mor diso, non é ata mediados do século XVIII que podemos dar cifras xerais da transmisión do seu nome.

Como se pode ver na táboa 1 , a transmisión dos nomes da familia carnal non era moi elevada. No século XVII, pártese de cifras baixas: o $6,79 \%$ dos pais e o $4,53 \%$ das nais transmiten o seu nome. Non existía, por tanto, costume de repetir os nomes paternos entre a prole. Habería excepcións, especialmente nas familias nobres ou mellor acomodadas que empregaban o nome como distintivo familiar (Zabalza Seguin 1999: 328); como, por exemplo, o capitán don Miguel Ares de Cedrón e a súa esposa dona Francisca de Villamarín que asignaron o nome paterno a un fillo, Miguel Antonio (1655), e o da nai a outro, Francisco (1656), mais o primoxénito recibira o nome de Froilán ${ }^{8}$. A práctica de transmitir o nome dos pais non tiña gran percorrido na zona e a citada función de elemento distintivo da familia recaía máis frecuentemente no apelido.

Conforme avanzan os séculos XVII e XVIII foise incorporando a práctica da transmisión dos nomes paternos. Especialmente destacado foi o incremento das nais no século XVII que se situaron en cotas de transmisión superiores ao pai; porén, foi na segunda metade do século XVIII cando se acadaron os maiores índices: nos anos centrais, o $14,56 \%$ dos bautizados recibían o nome do pai e nos últimos anos da centuria o $16,37 \%$ o da nai. A principal causa deste incremento foi o auxe e expansión dos nomes múltiples. Tras apareceren na zona lucense na segunda metade do século XVII, non só se converteu nunha práctica xeneralizada en todos os sectores da poboación, senón que o número de nomes asignados multiplicouse.

Os nomes múltiples permitían a transmisión de máis persoas, polo que se aproveitou para crear un vínculo entre o bautizado e as máximas persoas posibles. Os pais participaron desta moda transmitindo en máis ocasións, pero sen excederse para non crear demasiados casos de homonimia no fogar. Outra ferramenta que empregaron foi non asignar o nome sempre en primeiro lugar, senón como segundo ou terceiro para que así o cativo tivese outra referencia onomástica coa que ser identificado. A modo ilustrativo podemos destacar que na vila de Sarria nos anos 1750-1756, oito cativos foron bautizados co nome de seu pai como primeiro e quince como segundo ou terceiro.

Nas nais, a situación amósase máis equilibrada como consecuencia da forte presenza do nome de María que, neses anos, representaba un cuarto dos nomes asignados ás nenas. En total, nos anos centrais do século XVIII, o $52 \%$ das nenas recibiron ese nome, o que unido á que se tendía a asignalo como primeiro nome, era que máis homonimia causaba. De aí que todas as orixes onomásticas femininas -nai e avoas de ambas ramas- transmitisen máis cós seus conxéneres masculinos e prolongasen a evolución positiva ata o século XIX, cando se introduciron na antroponimia lucense os nomes procedentes das advocacións marianas que, ao comezo, sempre ían acompañadas do nome de María (González Lopo 1992: 179-180).

\begin{tabular}{|c|c|c|c|c|c|c|c|} 
& $\begin{array}{c}\text { Inicios } \\
\text { s. XVII }\end{array}$ & $\begin{array}{c}\text { Mediados } \\
\text { s. XVII }\end{array}$ & $\begin{array}{c}\text { Tránsito ss. } \\
\text { XVII-XVIII }\end{array}$ & $\begin{array}{c}\text { Mediados } \\
\text { s. XVIII }\end{array}$ & $\begin{array}{c}\text { Tránsito ss. } \\
\text { XVIII-XIX }\end{array}$ & $\begin{array}{c}\text { Mediados } \\
\text { s. XIX }\end{array}$ & $\begin{array}{c}\text { Tránsito ss. } \\
\text { XIX-XX }\end{array}$ \\
\hline Pai & $6,79 \%$ & $6,86 \%$ & $11,68 \%$ & $14,56 \%$ & $11,90 \%$ & $9,98 \%$ & $6,15 \%$ \\
\hline Nai & $4,53 \%$ & $8,29 \%$ & $12,36 \%$ & $15,24 \%$ & $16,37 \%$ & $10,80 \%$ & $10,13 \%$ \\
\hline Avó paterno & - & - & - & $10,88 \%$ & $11,97 \%$ & $8,14 \%$ & $7,38 \%$ \\
\hline Avoa paterna & - & - & - & $11,34 \%$ & $15,21 \%$ & $10,27 \%$ & $11,51 \%$ \\
\hline Avó materno & - & - & - & $8,72 \%$ & $10,25 \%$ & $8,11 \%$ & $7,42 \%$ \\
\hline Avoa materna & - & - & - & $11,98 \%$ & $13,03 \%$ & $12,64 \%$ & $12,19 \%$ \\
\hline $\mathrm{N}^{\mathrm{o}}$ Bautizados & 1016 & 1894 & 2816 & 2822 & 3024 & 3047 & 2616 \\
\hline
\end{tabular}

Táboa 1. Evolución da transmisión do nome da familia carnal 
Ao longo do século XIX, a transmisión de todos os membros da familia carnal decae como consecuencia de dous factores. A propia evolución do fenómeno dos nomes múltiples afectaba directamente á transmisión destes sectores; logo, o retorno a un sistema antroponímico máis simple -un ou dous nomes en xeral- foi en detrimento da presenza da familia carnal na onomástica.

$\mathrm{O}$ outro factor que entrou en xogo foi a mutación dos perfís de padriños; no século XIX aumentou a tendencia a escollelos entre a parentela máis próxima: avós e tíos. A frecuente transmisión do nome dos parentes espirituais, que abordamos no seguinte apartado, provocaba que ao confluíren parentes espirituais e carnais na mesma persoa a circulación de nomes e a renovación do repertorio só tivese lugar entre os nomes existentes dentro da familia e non da comunidade. Entón, para evitar unha esaxerada homonimia dentro do fogar, optouse por reducir a transmisión dos pais e avós e procuráronse outros novos fóra das fontes tradicionais; así, paliouse a homonimia e ampliouse o repertorio onomástico.

Por conseguinte, a evolución da transmisión dos nomes dos avós e pais presentou diferenzas con outras áreas en función dos perfís de padriños predominantes en cada unha e do momento e da intensidade do fenómeno dos nomes múltiples. Así, por exemplo, en Portugalete (Euskadi), a transmisión do nome dos pais xa estaba diminuíndo no século XVIII (Hanicot Bourdier 2006: 4). Mesmo proceso de perda de transmisión que se observa en zonas francesas entre o século XVII e o XVIII (Goujard 1984: 205); diferenzas que radican nunha fusión máis temperá de familia carnal e espiritual.

Mais non debemos desprezar outros factores como o modelo de estrutura familiar e o entorno rural ou urbano. $\mathrm{O}$ valor de patrimonio familiar que tiña o nome e as súas pautas de transmisión estaban condicionadas pola extensión e modelo de familia, en tanto se trataba de construcións sociais (Salinero 2010: 12). Por exemplo, Zabalza Seguin apunta como hipótese que nas zonas de herdeiro único e modelos familiares nucleares existía tendencia á homonimia entre irmáns porque estaban condenados a separarse (Zabalza Seguin 2005:
248). No caso lucense, a homonimia entre irmáns era infrecuente entre fillos do mesmo sexo, non así entre irmáns home-muller; como os dous fillos de Rafael Fernández e Rosenda Gancedo -Ramón (1849) e Ramona (1851) ${ }^{9}$. A existencia de homonimia entre os irmáns circunscríbese aos nomes múltiples ou, nalgúns casos, á morte previa do primeiro bautizado. En 1848, Manuel Pérez e María Pérez bautizan ao seu fillo Manuel, o cal falece párvulo; en 1850, o seguinte fillo da parella recibe tamén o nome de Manuel ${ }^{10}$. Ao contrario que na área estudada por Zabalza Seguin, na diocese de Lugo había un elevado grado de corresidencia de irmáns -o casado na casa e os solteiros que permanecían no fogar paterno-, polo que a homonimia entre eles perseguiríaos toda a vida e suporía un obstáculo á convivencia.

A persoa elixida para transmitir o nome a cada fillo estaba en directa relación coa posición máis probable que lle ía corresponder a cada un no futuro: perpetuar a casa, emigrar ou ficar solteiro no fogar. Os que recibiron o nome paterno en maior medida foron os fillos máis pequenos (Carretero Melo 2001: 53), os cales non estaban destinados a dirixir a casa, mais si a formar parte activa dela, xa que os irmáns solteiros no fogar contribuían ao mantemento económico e social da casa. Polo tanto, os pais garantían que na casa ficaría o seu nome, aínda que non polo fillo que sería o cabeza de casa, e non se desbotaba a posibilidade de que ese nome se transmitise a seguinte xeración, xa fose dende a figura do avó ou dende a figura de padriño ao seren estes tíos solteiros os padriños dos fillos máis pequenos da seguinte xeración.

Ao tratarse dunha zona cun destacado papel das familias extensas, hai que analizar quen era o cabeza de casa, xa que a constelación do poder diverxía se aínda se mantiña o avó ou se, pola contra, era xa o pai do bautizado. Para ilustrar isto amosamos a elección dos nomes dos fillos de José Lobelle e Juan Conde, ambos veciños da freguesía de Santo Estevo de Cartelos entre 1730-1760. José consta no Catastro da Ensenada como cabeza de casa dunha familia nuclear: el e a súa dona, Francisca Vázquez, xunto con dous fillos. Para ambos, escóllese o nome paterno: María Josefa e José Andrés. O único reflexo dos avós na antroponimia é no neno, posto que o avó materno chámase 
Andrés; pero prodúcese un caso de homonimia entre o avó e o padriño, Andrés Pérez. Aínda que a elección do nome de Andrés estivese motivada pola figura do avó e non pola do padriño, podemos considerar un signo da estrutura de poder interna da familia a súa colocación en segundo lugar tras o nome do pai ${ }^{11}$.

Pola súa parte, Juan Conde e a súa esposa Josefa Fernández teñen unha prole máis numerosa -seis nenas e dous nenos-; pero viven xunto cos avós paternos, Antonio Conde e Dorotea Fernández, que no Catastro da Ensenada mantéñense como cabezas de casa, a pesar de superar Antonio os setenta anos. Entre a prole de Juan non se atopa ningún cativo que reciba o nome do pai e, pola contra, os dous nenos levan o nome de Antonio -Fernando José Antonio e Domingo Antonio- e unha das nenas o nome de súa avoa -Dominga Feliciana Dorotea $^{12}$. En consecuencia, podemos afirmar que as regras de transmisión do nome eran elásticas para poder adecuarse ao modelo familiar no que se estaba inserto.

O exemplo citado tamén exemplifica a correlación que existía entre o sexo do transmisor e do receptor, malia que era flexible e a transmisión cruzada entre sexos tamén tiña o seu espazo; é dicir, un neno tiña máis posibilidades de recibir o seu nome dun referente masculino - pai, padriño ou avós- e unha nena dunha feminina -nai, madriña e avoas. Esta característica da transmisión é común e estendida tanto en Galicia coma na península (Rey Castelao 2015: 209; Castro Díaz 2011: 451; Ansón Calvo 1977: 79), aínda que diverxe no volume de cada transmisor. O pai transmitiu o seu nome ao $12,87 \%$ dos fillos varóns, pero só ao 7,23\% das fillas; pola súa parte, as fillas recibiron o nome materno no $16,20 \%$ dos casos e os fillos no $7,74 \%$. Entre os avós mantense a tendencia, sendo o avó materno o que maior equidade na transmisión acadou $(6,05 \%$ de nenas e $11,75 \%$ dos nenos).

A transmisión dos nomes paternos tiña un maior impacto nas áreas urbanas, en tanto foron na cidade de Lugo e noutras vilas, como Sarria ou Monforte de Lemos, onde se acadaron os maiores índices por parte dos pais. Nos anos centrais do século XVIII, o 24,3\% dos bautizados en San Pedro de Lugo recibiron o nome do pai e outro $24,3 \%$ o da nai; en Sarria, nos mesmos anos, ao $23,5 \%$ asignábaselle o nome paterno e o $25,5 \%$ o materno. Por unha banda, foi nas áreas urbanas onde os nomes múltiples acadaron maior dinamismo e, por conseguinte, os pais transmitían en maior proporción. Porén, tamén era nesas zonas onde se producía unha menor identificación do bautizado cos proxenitores, coa familia e coa casa á que pertencía por mor da concentración de poboación. Así pois, é posible que nas urbes se transmitise o nome dos pais como un xeito de facilitar a identificación da ligazón familiar do novo membro. Por outra banda, en relación ao que acabamos de expor sobre as estruturas familiares, era nas áreas urbanas onde as familias nucleares tiñan un maior peso: o $68,3 \%$ na cidade de Lugo e o $66,5 \%$ na vila de Monforte de Lemos (Sobrado Correa 2001b: 74; Dubert García 1992: 145). Namentres, en comarcas rurais tiñan unha menor presenza e, incluso, podían seren máis habituais os modelos complexos, coma na comarca de Guntín ou Cervantes onde as familias de estrutura complexa superaban o $52,9 \%$ e $59,7 \%$, respectivamente (Sobrado Correa 2001a: 90-91).

A baixa transmisión do nome por parte dos parentes carnais estriba, por tanto, en dúas cuestións. Por unha banda, priorízanse os nomes alleos á familia carnal para evitar a homonimia no fogar; e, por outra banda, antepóñense os nomes dos padriños nun xeito de gañar o favor destes cara ós afillados e de evidenciar ante a comunidade a existencia dese lazo.

\subsection{Nomes da familia espiritual}

No bautismo, o pequeno vuelve otra vez a nacer espiritualmente (Vega 1602: 79), momento no que contraía parentesco espiritual el e seus pais cos padriños, converténdose estes nos seus pais espirituais. Dende o Concilio de Trento, o número de padriños máximo eran dúas persoas de distinto sexo; mais a Igrexa consideraba que o ideal era que só unha persoa exercese de padriño (Alfani 2009a: 88). Na diocese de Lugo, a poboación optou maioritariamente polo modelo de parella -padriño e madriña-, porén en determinados períodos e áreas a opción dunha soa persoa acadou gran éxito (González López 2016: 91). 
Ata o Concilio de Trento, o número de padriños era ilimitado e libre. Guido Alfani amosou como en Italia se chegaban a seleccionar unha ducia de persoas para apadriñar a cada fillo (Alfani 2009b: 59-62), contexto no que resultaba inviable que os padriños transmitisen o seu nome ao afillado. Con todo, os cambios propiciados polo Concilio puideron ser os detonantes do incremento da transmisión do nome por parte dos padriños. Como se pode ver na táboa seguinte, a inicios do século XVII, tanto o padriño como a madriña non transmitían o seu nome máis có $8,17-8,46 \%$; pero estas cifras non pararon de medrar ata inicios do século XIX e, incluso entón, a transmisión dos padriños duplicaba sobradamente as porcentaxes de inicios do século XVII. Ao eliminarse en Trento os modelos de apadriñamento múltiples, iniciouse un proceso de individualización e revalorización dos padriños ao converterse nunha relación que abarcaba a menos persoas e, por conseguinte, máis próxima. Ao ser máis estreita a relación creada, buscouse que dita relación adquirise un cariz público a través da onomástica; amais, a homonimia entre padriño e afillado reforzaba o vínculo e unía ás familias.

O empuxe definitivo á buscada homonimia de padriños e afillados veu da man dos nomes múltiples que permitían transmitir tanto o do padriño como o da madriña. Así, na primeira metade do século XVIII, non foi infrecuente que se optase pola fórmula de asignar en primeiro lugar o nome de padriño e de segundo o da madriña, se o bautizado era un neno, e á inversa, se era unha nena. Benito Antonio (San Pedro de Besteiros, 1714) debía o seu nome ao seu padriño, o presbítero Benito de Aguiar, e á súa madriña, Antonia de Gaioso ${ }^{13}$. Conforme medrou o número de nomes que se asignaban, incorporouse a familia carnal á transmisión, pero sen restar espazo á familia espiritual. En ocasións, era a imposibilidade de masculinizar ou feminizar o nome dos padriños o que deixaba espazo á transmisión da familia carnal. Lucía Antonia (Quinta de Lor, 1713), a filla maior de Alexandro Macía e Teresa González, recibiu o nome de súa madriña, Lucía Rodríguez de Castro, e de seu padriño, Antonio Rodríguez Piñeira. A seguinte filla, María Teresa (1712), debía o seu primeiro nome á madriña, dona María Antonia, pero o padriño, Diego Gómez, posuía un nome que non se feminizaba, polo que o segundo nome foi o da nai ${ }^{14}$.

Ao igual que acontecía coa familia carnal, existía unha correlación entre o sexo do transmisor e o do receptor do nome, que tamén se constata noutras áreas peninsulares e europeas (Lema Suárez 2006: 166; Ballesteros Díez 2004: 37; Burguière 1984: 29; Dürr 1984: 191). Secasí, a transmisión cruzada da familia espiritual -padriños ás afilladas e madriñasbeneficiaba aos varóns, polo que os padriños se erixiron como o baluarte principal da transmisión. Mentres as madriñas transmitían aos afillados o $13,88 \%$ dos nomes, os padriños facíano no $19,81 \%$ dos nomes das súas afilladas; se a iso se engade o auxe do modelo de padriño individual que tivo lugar no século XVIII que se cimentou no sector masculino, explícase o leve aumento da transmisión do nome das madriñas no século XVIII: o $30 \%$ dos bautizados recibiron só un home como padriño, polo que non había madriña para dar o nome.

Como xa comentamos, no século XIX perdeu espazo a práctica dos nomes múltiples e retornouse aos simples. Isto implicaba que, salvo que houbese homonimia no entorno, só se asignaba o nome dunha persoa, polo que descenderon as taxas de transmisión de todos os sectores. De igual xeito, o mencionado cambio nos perfís de padriños pola selección dentro da familia carnal levou parello que, para evitar casos sangrantes de homonimia, se optase por outros nomes alleos aos padriños. A maiores, produciuse unha tendencia á repetición de padriños para todos ou varios fillos, polo que precisábase buscar outro nome distinto para evitar

\begin{tabular}{|c|c|c|c|c|c|c|c|}
\hline & $\begin{array}{c}\text { Inicios } \\
\text { s. XVII }\end{array}$ & $\begin{array}{c}\text { Mediados } \\
\text { s. XVII }\end{array}$ & $\begin{array}{c}\text { Tránsito ss. } \\
\text { XVII-XVIII }\end{array}$ & $\begin{array}{c}\text { Mediados } \\
\text { s. XVIII }\end{array}$ & $\begin{array}{c}\text { Tránsito ss. } \\
\text { XVIII-XIX }\end{array}$ & $\begin{array}{c}\text { Mediados } \\
\text { s. XIX }\end{array}$ & $\begin{array}{c}\text { Tránsito ss. } \\
\text { XIX-XX }\end{array}$ \\
\hline Padriño & $8,17 \%$ & $14,84 \%$ & $31,25 \%$ & $52,73 \%$ & $54,30 \%$ & $30,46 \%$ & $23,17 \%$ \\
\hline Madriña & $8,46 \%$ & $15,36 \%$ & $25,04 \%$ & $36,18 \%$ & $42,79 \%$ & $28,91 \%$ & $21,98 \%$ \\
\hline $\mathrm{N}^{\circ}$ Bautizados & 1016 & 1894 & 2816 & 2822 & 3024 & 3047 & 2616 \\
\hline
\end{tabular}

Táboa 2. Evolución da transmisión do nome da familia espiritual 
a homonimia. Por exemplo, dos doce fillos de Antonio Fernández e María Aguiar (Santo Estevo de Cartelos), nados entre 1894 e 1919, dez tiveron por padriño a Agustín Fernández, tío paterno, e once a Dolores Fernández, tía paterna, e residentes ambos na casa dos pais. Foron os únicos padriños da prole, dado que a penúltima só recibiu de madriña a Dolores e para o último non constan os padriños. De todos eles, ningún recibiu o nome do padriño e só a penúltima o nome da madriña ${ }^{15}$.

Con todo, non supuxo a perda total da capacidade nominativa dos padriños, xa que a finais do século XIX o 4,6\% dos padriños e o $2,46 \%$ das madriñas que tiñan máis dun afillado impuxéronlles a todos eles o seu nome. Das cinco ocasións entre 1878 e 1882 que o veciño de Sarria, don José María Rodríguez, sostivo a un cativo na pía bautismal como padriño, en catro delas o bautizado recibiu o nome de José María; a única excepción foi un dos xemelgos que apadriñou en 1882 quen se chamaron José María e Manuel ${ }^{16}$. Amais, a escolla do nome do afillado non tiña que ser o propio nome dos padriños, senón que podían optar por outros que fosen santos da súa devoción ou, sinxelamente, que lles gustase. A finais do século XIX, $10,3 \%$ das madriñas e o $11,5 \%$ dos padriños de varios cativos déronlles a todos o mesmo nome, que non era o propio deles. Por exemplo, don Manuel Arias Valcarce e Manuela García Saavedra nominaron aos seus dous afillados co nome de Modesto; no primeiro deles, o máis plausible é que o escollesen polo santo do día, xa que nacera pola onomástica do santo en xuño de 1876. A elección do nome do segundo estivo marcada polo falecemento do afillado anterior ${ }^{17}$.

A traxectoria da evolución da transmisión por parte dos padriños foi semellante á doutras áreas, pero ao estar condicionada polo fenómeno dos nomes múltiples e dos modelos de apadriñamento predominantes, o calendario que seguiu foi diferente. Por exemplo, a diminución da transmisión que tivo lugar no século XIX en Lugo, anticipouse ao século XVIII en zonas francesas (Goujard 1984: 204-205). Pola contra, no occidente galego, o descenso no século XIX non tivo lugar, senón que foi o período no que máis padriños deron o seu nome aos afillados (Lema Suárez 2006: 160). Noutras parroquias desa zona si houbo descenso no século XIX, pero, dende logo, moito máis atenuado ca en Lugo: na zona do Eume, o $92,8 \%$ dos bautizados entre 1775-1790 eran homónimos de seus padriños, en 1835-1850 eran o 85,9\% (Castro Díaz 2011: 452).

Ademais de familia espiritual, os padriños eran membros da comunidade, xa que máis do $60 \%$ eran veciños da mesma parroquia có seu afillado. Por tanto, a través dos padriños, existía unha circulación de nomes no seo da comunidade que facilitaba a cohesión veciñal polo lazo creado, pero que tamén contribuía a aliviar a homonimia dentro da propia familia.

\subsection{Nomes dos santos da comunidade}

Catalogamos como nomes dos santos da comunidade aqueles que aludían a algún santo presente na parroquia a través dunha freguesía, capela, ermida ou santuario; así como na contorna posto que o culto a determinados santos rebordaba o límite parroquial. Porén, non se trataba da única orixe de corte relixioso que podía haber, xa que os santos que se celebraban no día de nacemento ou no do bautismo tamén tiñan un espazo destacado -terceira causa de asignación de nomes-, alén das devocións individuais de padriños e pais.

Dende unha ollada externa, estes citados nomes serían os que mellor representarían o sentido da comunidade, xa que eran o obxecto de culto das prácticas relixiosas compartidas e estas eran as que contribuían a marcar quen pertencía á comunidade (Saavedra Fernández 2009: 91). A parroquia era unidade de organización territorial básica ao redor da que se organizaba a comunidade no ámbito relixioso, laboral e social (Sobrado Correa 2012: 707718). En efecto, ao longo do Antigo Réxime, foi medrando a identificación da poboación coa parroquia, grazas ao fomento que a Igrexa fixo de dita adscrición a partir do Concilio de Trento e que en Lugo comezou a calar no século XVIII.

Esta parece ser a causa principal do incremento leve da asignación do nome do patrón

ACPDLu, Libro III de Bautismos (1877-1925), San Estevo de Cartelos, f. 31v-84v.

16 ACPDLu, Libro V de Bautismos (1866-1882), O Salvador de Sarria, Vilar y San Martiño de Requeixo, f. 90, 96, $119 \mathrm{v}$ e $140 \mathrm{v}$.

17 ACPDLu, Libro IX de Bautismos de Santa María (1865-1880), Quinta de Lor, f. 148 e 180v. 


\begin{tabular}{|c|c|c|c|c|c|c|c|}
\hline & $\begin{array}{c}\text { Inicios } \\
\text { s. XVII }\end{array}$ & $\begin{array}{c}\text { Mediados } \\
\text { s. XVII }\end{array}$ & $\begin{array}{c}\text { Tránsito ss. } \\
\text { XVII-XVIII }\end{array}$ & $\begin{array}{c}\text { Mediados } \\
\text { s. XVIII }\end{array}$ & $\begin{array}{c}\text { Tránsito ss. } \\
\text { XVIII-XIX }\end{array}$ & $\begin{array}{c}\text { Mediados } \\
\text { s. XIX }\end{array}$ & $\begin{array}{c}\text { Tránsito ss. } \\
\text { XIX-XX }\end{array}$ \\
\hline $\begin{array}{c}\text { Patrón } \\
\text { Parroquia }\end{array}$ & $5,12 \%$ & $6,18 \%$ & $7,99 \%$ & $7,97 \%$ & $7,87 \%$ & $5,81 \%$ & $10,24 \%$ \\
\hline No $^{\circ}$ bautizados & 1016 & 1894 & 2816 & 2822 & 3024 & 3047 & 2616 \\
\hline
\end{tabular}

Táboa 3. Evolución da transmisión do nome do patrón parroquial

da parroquia durante o século XVII e o estancamento no século XVIII. Como se ve na táboa 3 , houbo un certo equilibrio entre o $5,12 \%$ e o $7,97 \%$, agás a finais do século XIX, cando se disparou ata o $10,24 \%$. Son cifras tenues que estaban por baixo de transmisión da familia carnal e, claramente distantes, da familia espiritual.

Dicimos parece porque había outros factores que propiciaron esta transmisión que non tiñan nada que ver coa maior cohesión parroquial: os nomes múltiples e o nome de María. A evolución da asignación do nome do santo titular foi paralelo ao auxe dos nomes múltiples; conforme se asignaban máis nomes, incrementouse o espazo para asignar o nome do patrón da parroquia. Isto significa, por tanto, que era un nome prescindible, de aí que cando se tendeu novamente aos nomes simples, no século XIX, diminuíse a asignación do nome do patrón da parroquia. A maiores, unha quinta parte das parroquias galegas estaban baixo a advocación da Virxe María, culto que se fomentou a partir do Concilio de Trento co seu consecuente reflexo na antroponimia. A mediados do século XVI, na diocese de Lugo asignábase o nome de María ao 12,77\% das bautizadas, segundo nome en frecuencia tras Catalina; mais no século XVII a súa asignación xa medrara ao 27,89\% (González López 2018: 314-316). Este fenómeno tivo lugar tanto nas parroquias baixo advocación da Virxe coma no resto, polo que atribuír a asignación do nome de María só a que era a patroa da parroquia sería erróneo. Isto vese corroborado pola diferente transmisión do santo titular segundo o sexo do bautizado. No século XVII e XVIII, máis do $81 \%$ dos que recibiron o nome do santo titular eran nenas; no século XIX, comeza a equilibrarse a transmisión e xa eran nenos o $31 \%$ dos receptores.

O novo auxe da asignación do nome do patrón da parroquia a finais do século XIX, cando alcanza o $10,24 \%$ poderíase tratar de explicar con base na emigración, como un xeito de simbolismo ou morriña ante a posible emigración a América dos proxenitores ou do propio bautizado que levaría, así, un símbolo do seu lugar de orixe. Pero ao analizar máis detalladamente os datos por parroquias, debemos rexeitar totalmente esta posibilidade. Aínda que resulte paradoxal, esa mesma simplificación dos nomes que levou á redución da asignación do patrón parroquial na primeira metade no século XIX explica ao mesmo tempo ese novo aumento, xa que se debeu exclusivamente ás parroquias que tiñan á Virxe como titulares. Ao simplificarse os nomes, María saíu reforzado e, ademais, ao longo do século XIX, os nomes marianos adquiriron un forte protagonismo que, na meirande parte dos casos, eran acompañados do nome de María. Por exemplo, na naviega parroquia de Santa María de Rao o $61,58 \%$ dos bautizados recibiron a finais do século XIX o nome de María, polo que predominaban os nenos chamados Manuel María e José María e as nenas María Manuela ou só María.

Así pois, xunto coa evolución temporal, cómpre matizar as cifras no tocante ao santo titular, porque é evidente que algúns tiveron maior éxito ca outros (Augustini 1989: 447). A orixe das parroquias galegas sitúase na Idade Media e, salvo contadas excepcións, o santo titular asignado daquelas mantívose ata a actualidade. Vinte santos concentran o $85 \%$ das advocacións das parroquias e só tres eran mulleres: a Virxe María $\left(1^{\circ}\right)$, santa Eulalia/ Baia $\left(8^{\circ}\right)$ e santa Mariña $\left(10^{\circ}\right)$ (Navaza Blanco e García Pazos 2009: 192-196). Amais da antigüidade, debemos ter en conta a citada correlación do sexo do transmisor e receptor do nome que, malia seren santos, mantíñase no caso dos nenos quen recibiron o nome por unha santa en ínfimas ocasións; a única excepción foi a asignación debida á Virxe María. Pola contra, ás nenas fóronlles asignados os nomes feminizados dos santos en numerosas ocasións. A isto axudou, por unha banda, o menor repertorio de santas e, por outra banda, a menor tendencia a masculinizar o nome destas. A feminización de nomes masculinos xa se atopa, malia que de xeito esporádico, na Idade Media (Boullón Agrelo 2000: 133); en oposición, a masculinización de nomes femininos foi unha rareza e só se produciu cando se trataba dun nome previamente feminizado. 
Se tomamos as cifras por santos titulares das parroquias, amósase unha clara diferenciación da transmisión segundo quen fose, que se pode clasificar en tres comportamentos. En primeiro lugar, as parroquias adscritas á Virxe María, nas que a porcentaxe de cativos que recibe o nome ascende ao $21,55 \%$, unha cifra alta e máis en comparación coas restantes. Un segundo comportamento preséntase nas freguesías adscritas a san Pedro, san Vicente, san Xoán e san Lourenzo que, se ben non foron nomes moi asignados, si tiveron un espazo constante. Por último aquelas nas que asignar o nome do patrón da parroquia supoñía unha autentica excepción: Cristovo, Martiño, Nicolás, Paio, Estevo...

\begin{tabular}{|c|c|c|c|}
\hline María & Asignacións & $\begin{array}{c}\text { Total } \\
\text { bautizados }\end{array}$ & $\mathbf{\%}$ \\
\hline Pedro & 83 & 4826 & 21,55 \\
\hline Vicente & 17 & 1833 & 4,53 \\
\hline Xoán & 10 & 708 & 2,40 \\
\hline Lourenzo & 11 & 607 & 1,97 \\
\hline Cristovo & 7 & 771 & 1,82 \\
\hline Martiño & 5 & 614 & 0,91 \\
\hline Nicolás & 3 & 583 & 0,81 \\
\hline Paio & 5 & 1018 & 0,49 \\
\hline Baia & 2 & 459 & 0,44 \\
\hline Salvador & 6 & 1478 & 0,41 \\
\hline Estevo & 2 & 513 & 0,39 \\
\hline Mariña & 3 & 1033 & 0,29 \\
\hline & & &
\end{tabular}

Táboa 4. Transmisión do nome dos distintos santos patróns das parroquias

Podemos entrever unha semellanza entre o rol destes santos na transmisión e a presenza que tiñan eses nomes de xeito xeral. Así, o primeiro grupo, María, e parte do segundo grupo, Pedro e Xoán, eran nomes fortemente arraigados na diocese, aínda que Pedro só na súa versión masculina. Vicente e Lourenzo eran, xunto con parte do terceiro grupo, nomes que estiveron presentes sempre, pero nunca formaron parte dos dez nomes máis asignados. Por último, había un grupo de nomes que, pese a ser coñecidos por seren santos patróns de parroquias, apenas deixaron marca no repertorio como Salvador, Eulalia/Baia ou Paio.

Os nomes deste último grupo participaron do repertorio exclusivamente grazas ao santo parroquial; por exemplo, fóra das parroquias desa advocación, só foron bautizados tres cativos como Paio e catro como Cristovo. No caso de Mariña, noutras parroquias asignouse en proporción semellante $-0,22 \%$ dos bautizados- e Baia, sempre baixo a forma Eulalia ou Ulalia, Ulalla, foi menos asignada $-0,07 \%$. Mais isto tamén aconteceu con outros nomes dos primeiros grupos; por exemplo, Pedro asignouse fóra delas ao $0,66 \%$ das nenas e ao $7,73 \%$ dos nenos, a pesar da posición privilexiada que tivo no repertorio dende o século XVI; igual aconteceu con Vicente $(1,38 \%)$, Lourenzo $(0,73 \%)$ ou Martiño $(0,41 \%)$.

Os únicos nomes que saíron favorecidos da comparación foron María, posto que as cifras aumentan ao $23,14 \%-43,86 \%$ das nenas e $8,17 \%$ dos nenos-, e Xoán que, nas parroquias da súa advocación asignouse ao 1,97\% dos nenos, pero fóra dela ao 7,27\%. Incluso, en certos casos o pulo dun nome debeuse a outros factores, pois, do contrario, non se explica que, de súpeto, en San Vicente do Pino se bautizase co nome de Vicenta -dentro dun nome múltiple- ao $18,52 \%$ das rapazas entre 1724-1729.

Para outras zonas tense defendido que os patróns das parroquias perderon valor antroponímico como consecuencia da difusión da normativa tridentina e a consecuente homoxeneización que pretendía (Zabalza Seguin 2008: 121-122). Na diocese de Lugo, a normativa tridentina penetrou tardiamente, no marco dunha reforma que pretendía a mellora da moral e formación dos párrocos lucenses; proceso do que non se constataron os primeiros resultados ata mediados do século XVIII (Dubert García 1996: 381). Nese senso, a leve caída que tivera lugar na segunda metade do século XVIII, seguida dun descenso máis acusado, cadraría con esta hipótese. En troques, na área occidental de Galicia, o patrón da parroquia era a terceira causa de asignación de nomes, tras padriños e pais (Fernández Castro 2010: 182), zona na que a normativa tridentina penetrara con antelación a Lugo. Por tanto, debemos valorar que o escaso peso dos santos patróns se debeu a que tampouco resultaban unha fonte onomástica atractiva para a poboación. Na zona occidental, a identificación coa parroquia parece ser superior á que había na área oriental, xa que o tipo de hábitat e a densidade de poboación provocaba que na área oriental houbese unha maior adscrición á aldea que, ao contrario que na área occidental, debilitaba a identificación coa parroquia (Sobrado Correa 2012: 718). Isto non implica que os habitantes da Galicia interior non se identificasen coa parroquia e non fosen conscientes da súa pertenza a ela, senón que o santo titular non constituía unha simboloxía tan arraigada. 
No seu lugar, habería unha adherencia devocional superior aos santos de capelas, confrarías ou ermidas. A fundación destas estaría máis preto temporalmente dos veciños cá fundación das parroquias e, por outra banda, estas estaban dedicadas a santos avogosos das necesidades cotiás da poboación (Fernández Cortizo 2007: 176). Na chantadina parroquia de San Paio de Muradelle existía dende antes de 1722, ano no que volveu ser fundada por don Juan Somoza Enríquez, unha ermida dedicada a San Antonio. Na segunda metade do século XVII, o nome de Antonio era o cuarto nome en frecuencias para os nenos e o oitavo para as nenas; tras a nova fundación, situouse primeiro e cuarto, respectivamente, e mantívose entre as tres primeiras posicións en ambos sexos ata inicios do século XIX. Nese intre, decae ata o sexto e noveno posto; tempo durante o cal se mandou derruír a ermida por indecente ${ }^{18}$. Pese á orde derrubamento, en 1820 seguía en pé e o cura iniciou un proceso para pescudar a quen pertencía o padroado da mesma que rematou con éxito ao arranxar o patrón a ermida coa axuda dos veciños nesa década. $\mathrm{O}$ nome de Antonio reflotou posicións na parroquia para os homes, aínda que no sector feminino sucumbiu ante os nomes marianos de recente introdución.

Emporiso, non representaban unha fonte onomástica tan importante como a dos santos patróns no occidente galego. Como apuntou Sobrado Correa, na cidade de Lugo había unha gran devoción a San Roque e a San Froilán, sen que chegasen a ser os nomes máis habituais (Sobrado Correa 1998: 70); aínda así, en determinados períodos, o nome de Froilán chegou a ser asignado ao $14 \%$ das bautizadas no século XVIII. Mais, na cidade de Lugo puideron ser outros os factores condicionantes do escaso peso destes santos da comunidade no repertorio: a emigración. Resultaría interesante ampliar esta análise aos patróns das freguesías de residencia e orixe de pais e avós, así como ás ermidas e capelas, xa que podería amosar unha pretensión a manter a orixe simbólica dos devanceiros. O estudo sobre os emigrantes italianos en América amosaba como na primeira xeración nada na emigración se mantiña o mesmo repertorio cós pais, en lugar de integrarse e participar da onomástica do lugar no que residían (Tonda e Rossebastiano 2014: $650)$. Así pois, non se pode desbotar a existencia deste comportamento entre a poboación que migrou dentro de Galicia. Por exemplo, un fillo dos donos da Casa de Feás (San Martiño de Fente, Monterroso), don Gumersindo Feás Lorenzo, casou para a vila de Chantada onde residiu e se bautizaron os seus fillo. A primeira filla, María Concepción (1897), recibiu o nome de súa avoa paterna, que amais foi a madriña; a segunda filla, nada en 1898, recibiu o nome de María Minia, nome da santa á que se erixira unha capela a carón da devandita casa (Bouza Álvarez 1990: 308) ${ }^{19}$. Nese caso, tratouse dunha asignación simbólica do nome que non só unía á cativa cos seus avós, senón que tamén co propio lugar de orixe de seu pai.

Tamén se debería incluír neste apartado o impacto das reliquias, culto que remaneceu nos séculos XVII-XVIII (Ibid. 23-32). O estudo do impacto que destas na antroponimia vese dificultado pola existencia de propietarios particulares, información á que só podemos acceder a través dos testamentos nos que non sempre se anotaba o santo do que procedía a reliquia (González Lopo 1993: 254-259). Tomando como base as reliquias que eran propiedade ou estaban depositadas nas parroquias, podemos aseverar que en xeral tiveron un impacto leve -incluso nulo en certas parroquiasna antroponimia. Aínda que o auxe do culto ás reliquias tivo lugar na Idade Moderna, é posible que algunhas das reliquias existentes en Galicia procedesen dos séculos anteriores polo que, ao igual que acontecía cos santos titulares das parroquias, non habería conexión entre a poboación e a devoción por esas reliquias.

Houbo excepcións que, pese a representar a introdución dun novo culto, foi aceptado axiña e deixou marca no repertorio. Tratouse de reliquias que por si soas ou polo santo ao que pertencían se adscribían ao perfil dos santos avogosos e útiles para a poboación. Así aconteceu con San Pegerto, santo cuxas reliquias foron 
trasladadas a San Miguel de Buciños (Carballedo) en 1831 e que espertou a devoción de toda a contorna ao converterse no santo protector dos mozos que ían ao servizo militar (Ferro Couselo 1972: 128). A pesares de que o seu traslado foi propiciado polas elites locais -o bispo de Valladolid, don José Antonio Ribadeneira, que conseguiu as reliquias era natural da Casa Grande de Loureiro, na parroquia de Buciños, pertencente a unha familia de fidalgos- e os cultos destes sectores privilexiados non acostumaban a entrelazarse coa devoción popular, a avogacía que facía san Pegerto era máis democrática e afectaba máis ás clases populares, en tanto as superiores podían pagar para eximirse do servizo militar. Así pois, aínda que o nome de Pegerto non foi nunca dos dez máis habituais, si penetrou con forza na antroponimia do século XIX, estendéndose por boa parte da diocese de Lugo, incluso ata a propia capital lucense, da de Ourense e traspasando as fronteiras cara Portugal.

En definitiva, na onomástica persoal non se reflectiu apenas o valor da comunidade, entendendo como tal o ámbito relixioso da mesma. A comunidade formada en torno á parroquia marcaba as pautas da vida relixiosa, social e, en boa medida, económica; non obstante, o impacto dos santos que as simbolizaban apenas tivo cabida na antroponimia, posto que se primaban os nomes dos membros físicos da comunidade.

\section{Conclusións}

A antroponimia contribuía a crear a identidade propia e específica de cada individuo do Antigo Réxime, que se complementaba cos restantes elementos identificativos como a familia, a parroquia e a comunidade. Ao mesmo tempo, estes elementos repercutían na antroponimia, xa que o nome escollido para o bautizado estaba condicionado polo contexto xeográfico e temporal; por conseguinte, o nome era parte da identidade e reflectía os restantes aspectos da identidade do seu portador. Parte dese rol que tiñan os nomes na identidade derivaban do valor intrínseco do nome no que coadxuvaban o significado social do nome, por ser o dunha orde relixiosa ou dun santo de devoción, e o significado familiar, ao poder ser simultaneamente o nome dun devanceiro ou dos padriños.

Nese senso, os nomes múltiples contribuíron ao fomento da inclusión deses significados sociais e familiares no nome de todos os bautizados. As cifras de transmisión amosan a escasa implantación deste fenómeno nos primeiros séculos da Idade Moderna que, como consecuencia do cambio na institución do apadriñamento, comezou a difundirse e multiplicouse a raíz da asignación de varios nomes.

A comunidade de pertenza estaba plasmada no nome, pero non entendida como adscrición devocional a un mesmo santo, senón baixo o concepto de comunidade como grupo de persoas que convivían e tiñan prácticas sociais comúns. En efecto, non eran os santos patróns das parroquias os que maior impregnación na antroponimia tiñan, senón aqueles outros cuxa devoción estaba viva e era compartida pola meirande parte da comunidade. Sen dúbida algunha, os principais actores da transmisión foron os padriños, especialmente cando non pertencían á familia directa, xa que a asignación do nome ao afillado amosaba publicamente a existencia dunha relación entre ámbalas familias e, por extensión, as consecuentes obrigas, axudas e fidelidades mutuas.

Nunha visión máis ampla, a recepción dun nome por un padriño dunha familia allea que, á súa vez, o recibira do seu padriño que tamén era doutra familia, significa que a través da homonimia imposta polo apadriñamento se creaba unha sorte de relacións intrafamiliares que se incorporaban ao resto de lazos e nexos sociais. De xeito análogo, a incorporación do novo membro na tradición onomástica da parroquia facilitaba a súa continuidade nas seguintes xeracións, polo que posuía, ademais, a función de conexión interxeneracional. Isto sen esquecer que a asignación do nome representaba un método de adulación e honra cara o transmisor, polo que esa continuidade antroponímica no seo da comunidade non deixaba de ser un xeito de valorizala. En efecto, malia que en certos momentos os proxenitores e padriños deberon optar por romper esa continuidade para evitar unha excesiva homonimia, procuraban escoller nomes que non arredasen ao cativo da comunidade.

En suma, a antroponimia constituía un patrimonio inmaterial que se recibía no bautismo, asemade da primeira rede social á marxe dos proxenitores: os padriños. O nome facía referencia á familia carnal e espiritual, pero, nun concepto máis amplo, aludía á comunidade na que se nacía polo que favorecía a integración do nado e reforzaba a cohesión interna da freguesía. 


\section{Referencias bibliográficas}

Alfani, Guido (2009a): Fathers and godfathers: spiritual kinship in early-modern Italy. England: Ashgate. (2009b): "Godparenthood and the Council of Trent: crisis and transformation of a social institution (Italy, XV-XVIIth centuries)", Obradoiro de Historia Moderna 18, pp. 45-69.

Alfani, Guido e Vincent Gourdon (2009): "Fêtes du baptême et publicité des réseaux sociaux en Europe occidentale. Grandes tendances de la fin du Moyen Âge au XX siècle", Annales de démographie historique 117 , pp. 153-189.

Ansón Calvo, María del Carmen (1977): "Sociología del bautismo en el siglo XVII", Cuadernos de investigación: Geografía e historia 3, pp. 69-90.

Augustini, Muriel (1989): "Noms de baptème dans quatre paroisses de la Beauce et du Perche au XVe siècle", Population 44, pp. 445-451.

Ballesteros Díez, José Antonio (2004): “Onomástica y mentalidades en el siglo XVI”, Espacio, tiempo y forma. Serie IV, Historia moderna 17, pp. 27-58.

Bedoya, Juan Manuel (1825): El Pueblo instruido en sus deberes y usos religiosos : ó Manual del cristiano para su arreglo diario y principales y más frecuentes ocurrencias de la vida. Santiago de Compostela: Imp. D. Juan Francisco Montero.

Boullón Agrelo, Ana Isabel (2007): “«Farruco, Paco, Fran»: datos históricos e evolución dos hipocorísticos en Galicia", Revista galega de filoloxía 8, pp. 8-56.

(2000): "Galician female names in the Middle Ages (from 13th to 15th)", en D. Kremer (ed.), Onomastik. Akten des 18. Internationalen Kongresses für Namenforschung. Trier, 12-17. April 1993. Band II. Namensysteme in interkulturellen Vergleich. Tübingen: Niemeyer, pp. 122-135.

Bouza Álvarez, José Luis (1990): Religiosidad contrarreformista y cultura simbólica del barroco. Madrid: Consejo Superior de Investigaciones Científicas.

Burguière, André (1984): "Prénoms et parenté", en J. Dupâquier, A. Bideau e M.-E. Ducreux (eds.), Le Prénom: mode et histoire: entretiens de Malher 1980. Paris: École de Hautes Études, pp. 29-35.

Carretero Melo, Antonio (2001): “Antroponimia en la edad moderna. El nombre de pila del varón”, Nouvelle revue d'onomastique 37-38, pp. 43-56.

Castro Díaz, Beatriz (2011): "Familia, apadriñamento e onomástica na bisbarra eumesa: unha aproximación histórico-etnográfica (séculos XVII-XIX)", Cátedra: revista eumesa de estudios 18, pp. 413-474.

Dubert García, Isidro (1996): “Alma de curas y Cura de almas. Moral y comportamientos eclesiásticos en la Galicia interior durante el Antiguo Régimen (1600-1830)", en M. V. García Quintela, Las religiones en la historia de Galicia. A Coruña: Universidade, Servizo de Publicacións, pp. 379-412.

(1992): Historia de la familia en Galicia durante la época moderna, 1550-1830: (estructura, modelos hereditarios y conflictividad). Sada: Ediciós do Castro.

Dürr, Michel (1984): "Prénoms et parenté. Liens entre prénoms et parrainage à Préty, 1690-1750", en J. Dupâquier, A. Bideau e M.-E. Ducreux (eds.), Le Prénom: mode et histoire: entretiens de Malher 1980. Paris: École de Hautes Études, pp. 189-202.

Fernández Castro, Juan Andrés (2010): "Os nomes dos devanceiros. Antroponimia estradense, séculos XVII e XVIII”, A Estrada. Miscelánea histórica e cultural 13, pp. 179-200.

Fernández Cortizo, Camilo J. (2007): “«Para que esta gente bárbara fuese política y doméstica y enseñada en la doctrina cristiana»: iglesia, Estado y reforma religiosa en Galicia (siglos XVI-XVII)", Manuscrits: Revista d'història moderna 25, pp. 157-186.

Ferro Couselo, Xesús (1972): "El Canónigo compostelano Ribadeneira, oidor y regente de la Rota Romana: su correspondencia con el obispo de Orense, D. Dámaso Iglesias (1827-29)", Compostellanum 17, pp. 117-162.

Fine, Agnès (1984): “Transmission des prénoms et parenté en Pays de Sault, 1740-1940”, en J. Dupâquier, A. Bideau e M.-E. Ducreux (eds.), Le Prénom: mode et histoire: entretiens de Malher 1980. Paris: École de Hautes Études, pp. 108-125.

González López, Tamara (2018): Prácticas colectivas en las comunidades parroquiales de la Galicia interior, siglos XVI-XIX. Tese de doutoramento inédita. Santiago de Compostela: Universidade.

(2016): “Apadriñamento no Arciprestado de Bolaño", Lucensia: miscelánea de cultura e investigación 53, pp. 87-103.

González Lopo, Domingo L. (1993): "El papel de las reliquias en las prácticas religiosas de los siglos XVII y XVIII”, en L. C. Álvarez Santaló e C. M. Cremades Griñán (eds.), Mentalidad e ideología en el Antiguo Régimen. Moratalla: Universidad de Murcia, pp. 247-260. 
(1992): “Onomástica y devoción: la difusión de nuevos cultos marianos en la Galicia mericional, durante los siglos XVIII y el XIX: el obispado de Tuy", Obradoiro de Historia Moderna 1, pp. 165-184.

González Reboredo, Xosé Manuel e Xosé Ramón Mariño Ferro (eds.) (1990): Nacemento, casamento e morte en Galicia: resposta á enquisa do Ateneo de Madrid, (1901-1902). Santiago de Compostela: Consello da Cultura Galega.

Goujard, Philippe (1984): "Le stock de prénoms en Pays de Caux, 1686-1795”, en J. Dupâquier, A. Bideau e M.-E. Ducreux (eds.), Le Prénom: mode et histoire: entretiens de Malher 1980. Paris: École de Hautes Études, pp. 203-207.

Hanicot Bourdier, Sylvie Nathalie (2006): "Ensayo sobre la religiosidad de una comunidad vasca en los siglos XVIII y XIX”, Procesos históricos: revista de historia, arte y ciencias sociales 10, pp. 15.

Herzog, Tamar (2007): "Nombres y apellidos ¿Cómo se llamaban las personas en Castilla e Hispanoamérica durante la época moderna?", Jahrbuch für Geschichte von Staat, Wirtschaft und Gesellschaft Lateinamerikas 44, pp. 1-36.

Kintz, Jean-Pierre (1984): "Societé luthérienne et choix des prénoms à Strasbourg, XVIe-XVIIe siècles", en J. Dupâquier, A. Bideau e M.-E. Ducreux (eds.), Le Prénom: mode et histoire: entretiens de Malher 1980. Paris: École de Hautes Études, pp. 231-239.

Lema Suárez, Xosé María (2006): Onomástica histórica dunha parroquia galega: Berdoias (1607-2000) I. Os nomes masculinos. Santiago de Compostela: Asociación Galega de Onomástica.

Moratinos y Santos, Matías de (1675): Constituciones Synodales del Obispado de Lugo. Compiladas, hechas y promulgadas por el Ilmo. Sr. D. Matías de Moratinos... en la synodo que se celebró en su Iglesia Catedral de la dicha Ciudad en el mes de Febrero de mil y seiscientos y sesenta y nueve años. Madrid: Imp. Ioseph Fernández de Buendía.

Muñoz López, María del Pilar (2001): Sangre, amor e interés. La familia en la España de la Restauración. Madrid: Marcial Pons.

Navaza Blanco, Gonzalo; García Pazos, Fernando (2009): "Parroquias e toponimia", en F. García Pazos, A Parroquia en Galicia: pasado, presente e futuro. Xunta de Galicia: Santiago de Compostela, pp. 181-201.

Presedo Garazo, Antonio (2004): "Dinámica de casa y reproducción social en la hidalguía gallega durante el siglo XVIII", Espacio, tiempo y forma. Serie IV, Historia moderna 17, pp. 117-142.

Rey Castelao, Ofelia (2015): "De la casa a la pila: hábitos y costumbres de bautismo y padrinazgo en Santiago de Compostela, siglos XVII-XVIII”, en I. Arias de Saavedra Alías e M. L. López Guadalupe Muñoz (eds.), Vida cotidiana en la Monarquía Hispánica: Tiempos y espacios. Granada: Universidad, pp. 195-214.

- (2002): "La diócesis de Lugo en la época moderna", en J. García Oro (coord.), Historia de las diócesis españolas. Iglesias de Lugo, Mondoñedo-Ferrol y Orense. Madrid: Biblioteca de Autores Cristianos, pp. 95-166.

Saavedra Fernández, Pegerto (2009): "A rede parroquial desde finais do século XV a mediados do XIX", en F. García Pazos, A Parroquia en Galicia: pasado, presente e futuro. Xunta de Galicia: Santiago de Compostela, pp. 77-104.

_ (1992): "Datos para un estudio comarcal da mortandade de "párvulos"en Galicia (fins do XVII mediados do XIX)", Obradoiro de Historia Moderna 1, pp. 79-95.

Salazar Acha, Jaime de (2005): "La utilidad de la genealogía para el conocimiento de la evolución de los usos onomásticos”, en J. L. Ramírez Sádaba (ed.), La Onomástica en Navarra y su relación con la de España: actas de las primeras Jornadas de Onomástica (Pamplona, 2003). Pamplona: Universidad Pública de Navarra, Servicio de Publicaciones, pp. 177-200.

Salinero, Gregorio (2010): "Sistemas de nominación e inestabilidad antroponímica moderna", en G. Salinero e I. Testón Núñez (eds.), Un juego de engaños: movilidad, nombres y apellidos en los siglos XV a XVIII. Madrid: Casa de Velázquez, pp. 9-26.

Sobrado Correa, Hortensio (2012): "Identidad parroquial y comunidad rural en la Galicia de la Edad Moderna", en M. J. Pérez Álvarez e A. M. García (eds.), Campo y campesinos en la España Moderna; culturas políticas en el mundo hispano. León: Fundación Española de Historia Moderna, pp. 705-718.

(2001a): Las tierras de Lugo en la Edad Moderna: economía campesina, familia y herencia, 15501860. A Coruña: Fundación Pedro Barrié de la Maza.

(2001b): La ciudad de Lugo en el Antiguo Régimen, siglos XVI-XIX. Lugo: Servicio de Publicacións Diputación Provincial de Lugo. 
(1998): "Evolución de las devociones populares en la Galicia interior del Antiguo Régimen a través de la onomástica", Boletín de estudios del Seminario "Fontán-Sarmiento" de hagiografia, toponimia y onomástica de Galicia 19, pp. 64-74.

(1996): "Transformaciones agrarias, estrategias hereditarias y crecimiento demográfica en las tierras lucenses, 1750-1860", Obradoiro de Historia Moderna 5, pp. 7-40.

Tonda, Alfredo Juan e Alda Rossebastiano (2014): "La onomástica de los emigrados italianos en Argentina", en J. Tort i Donada e M. Montagut i Montagut (eds.), Els nomes en la vida quotidiana. Actes del XXIV Congrés Internacional d'ICOS sobre Ciènces Onomàstiques. Barcelona: Generalitat de Catalunya, pp. 642-652.

Vega, Fray Alonso de (1602): Espejo de curas, utilissimo para todo genero de Ecclesiasticos, y principalmente para aquellos que tienen cargo de animas, por comprehenderse en el todo lo que les es necessario para cumplir con la obligacion que tienen. Madrid: Pedro Madrigal.

Zabalza Seguin, Ana (2008): "Nombres viejos y nombres nuevos: sobre la onomástica moderna", Memoria y civilización: anuario de historia 11, pp. 105-134.

(2005): "Identidades cambiantes: la formación del nombre y el apellido en la Navarra moderna", en J. L. Ramírez Sádaba (ed.), La Onomástica en Navarra y su relación con la de España: actas de las primeras Jornadas de Onomástica (Pamplona, 2003). Pamplona: Universidad Pública de Navarra, Servicio de Publicaciones, pp. 245-262.

(1999): "Con nombre y apellido: Casa, parentesco e identidad en el Pre-Pirineo de Navarra (15501725)”, Vasconia: Cuadernos de historia - geografia 28, pp. 317-332. 